\title{
The Development of Electricity Grid, Smart Grid and Renewable Energy in Taiwan
}

\author{
Hwa Meei Liou \\ Graduate Institute of Technology Management, National Taiwan University of Science and Technology, Taipei, Taiwan \\ Email: *liouhm@mail.ntust.edu.tw
}

How to cite this paper: Liou, H.M. (2017) The Development of Electricity Grid, Smart Grid and Renewable Energy in Taiwan. Smart Grid and Renewable Energy, 8, 163-177.

https://doi.org/10.4236/sgre.2017.86011

Received: March 15, 2017

Accepted: June 20, 2017

Published: June 23, 2017

Copyright ( $) 2017$ by authors and Scientific Research Publishing Inc. This work is licensed under the Creative Commons Attribution International License (CC BY 4.0).

http://creativecommons.org/licenses/by/4.0/

(c) (i) Open Access

\begin{abstract}
The grid has played a vital role in the evolution of the electricity market; from traditional to smart grids; from fossil fuel power generated electricity grid connections to the integration of other renewable energy forms such as solar and wind power; the grid has played a key role in each step in Taiwan's move towards energy transition. This study includes Taiwan's construction of its transmission and distribution network, the recently passed newly revised version of the Electricity Act with its revisions to its transmission and distribution related content, and policies promoting the smart grid as well as issues that the renewable energy grid has raised in both the technical and legal aspects. Taiwan's electricity supply system is made up of the northern, central and southern systems. The Transmission and distribution grid have been defined as a common carrier, maintaining state-owned monopoly. The smart grid has 6 main facets to promote, including smart generation and dispatch, smart transmission, smart consumers, smart grid electricity grid industry and the establishment of a smart grid environment. Due to the possible effects of the integration of renewable energy generated electricity, there is a vital need for the regulation of the grid's management and skills.
\end{abstract}

\section{Keywords}

Electricity Grid, Smart Grid, Renewable Energy

\section{Introduction}

From traditional electricity grids to smart grids, from power grids based on fossil fuels such as coal and petroleum to grids integrating renewable energy sources such as solar and wind power, the grid system itself plays a key role in the operation of the electricity market, revealing the evolution process of this market, in particular in light of the problems which climate change and global warming raise for us now and for countries around the world; these issues are ones that 
will have to be addressed as we face the future. Energy saving methods can be achieved through advancements in technology and the development of new forms of power grids, while improving the production of renewable energy and reducing emission levels of greenhouse gases; those are all key links in enabling Taiwan to move towards energy transition.

A trend towards liberalization of the power industry took place around the world in the 1980s, and this reformation of the power industry included the transmission and distribution line within the electricity industry. With power grids aging and the demand for power increasingly rising, the importance of investing in the both the broadening of the scope of current power grids as well as the maintenance becomes more obvious day by day. The installation of smart meters is able to manage demands and is also an important part of power grids modernization process.

From a legal perspective, the need for legislative amendments to support this process has been shown to be a vital factor in power industry reforms in past research. This includes updating legislation with amendments to both the management and technological aspects supporting new developments, while revising outdated legislation to keep up with the progress of leading countries worldwide. The purpose of this paper is in discussing the development of Taiwan's distribution and transmission power grid, the current status of attempts to promote a smart grid, and the affects of the newest revisions to power industry legislation on the scope and content of transmission and distribution as part of the electricity market's liberalization policy plans, as well as the effect of renewable energy integrated grid on traditional power grids and the legislative response needed. Finally, this paper will consider the development of power grid related energy policy and legislation in the US and Europe and discuss possible ways that such developments could help Taiwan as it continues to promote renewable energy development.

\section{Transmission and Distribution Network}

A country's power grid is part of its basic infrastructure, and the development of such power grids has a history of more than a hundred years [1], power systems include electric power generation, transmission, distribution and sale systems, and within this system, transmission and distribution are formed through a combination of transmission and distribution grid paths and power substations. Taiwan's power grid system is run by state owned Tai-Power, and can be separated into three main systems, the north, central and southern systems, respectively based in Xinzhu County, Fengshan River and Choshui River. Figure 1 and Figure 2 show the northern, central and southern electricity systems' power supply capacity and peak load of power utilization in 2015. We can see from these figures that both power utilization in the north and the northern system's supply level are higher than the central and southern systems, with utilization accounting for $39 \%$ while supply levels dropped to $34 \%$ meaning that the north is already reliant on the economic dispatch of power from the central and 


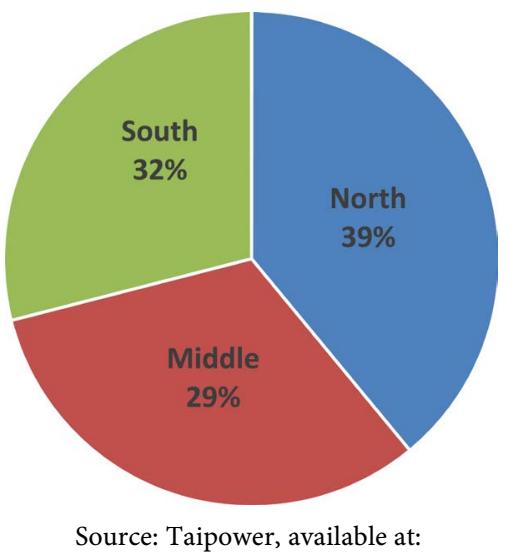

http://www.taipower.com.tw/content/new info/new info-c21.aspx?LinkID=12

Figure 1. Peak load of northern, central and southern Taiwan.

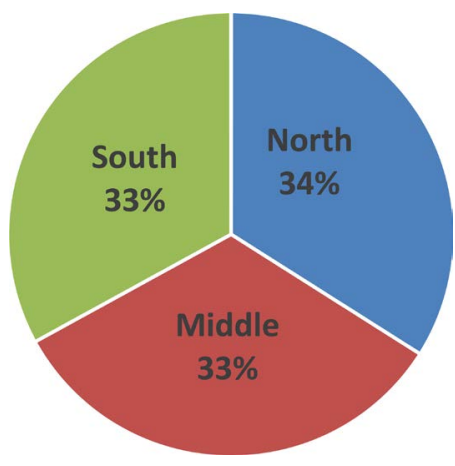

Source: Taipower, available at:

http://www.taipower.com.tw/content/new info/new info-c21.aspx?LinkID=12

Figure 2. Load capability of northern, central and southern Taiwan.

southern systems to the north. For optimum results both the generation of power and power use should occur identically within the same system; the central system's generated power accounts for $33 \%$ of all power generated nationally, a figure higher than the $29 \%$ peak load the central system consumes. While the southern system's generated power also stands at $33 \%$, slightly more than the system's peak load of $32 \%$. Only the northern system produces less power than its peak load consumes, leading to a situation where the northern system lacks power. As for why the northern system lacks enough power, the main reason is the densely populated nature of the area, leading to higher demands for power than in central and southern Taiwan. Taipower's Power Development Plan continues to emphasize the regional balance of power in order to decrease the trend of power being transmitted from the south to the north [2].

The process of power transmission is dependent on PSA levels, with the power system being dividable into three types, as Figure 3 shows: 1) Nuclear power, large scale hydropower and thermal power plants, the power produce from this type of plant having gone through a transformer produces $345 \mathrm{KV}$, making use of transmission lines to transmit energy and having passed through the power substation voltage is reduced to $161 \mathrm{KV}, 69 \mathrm{KV}$, providing large scale users in science parks, before going through a power distribution substation to reduce 


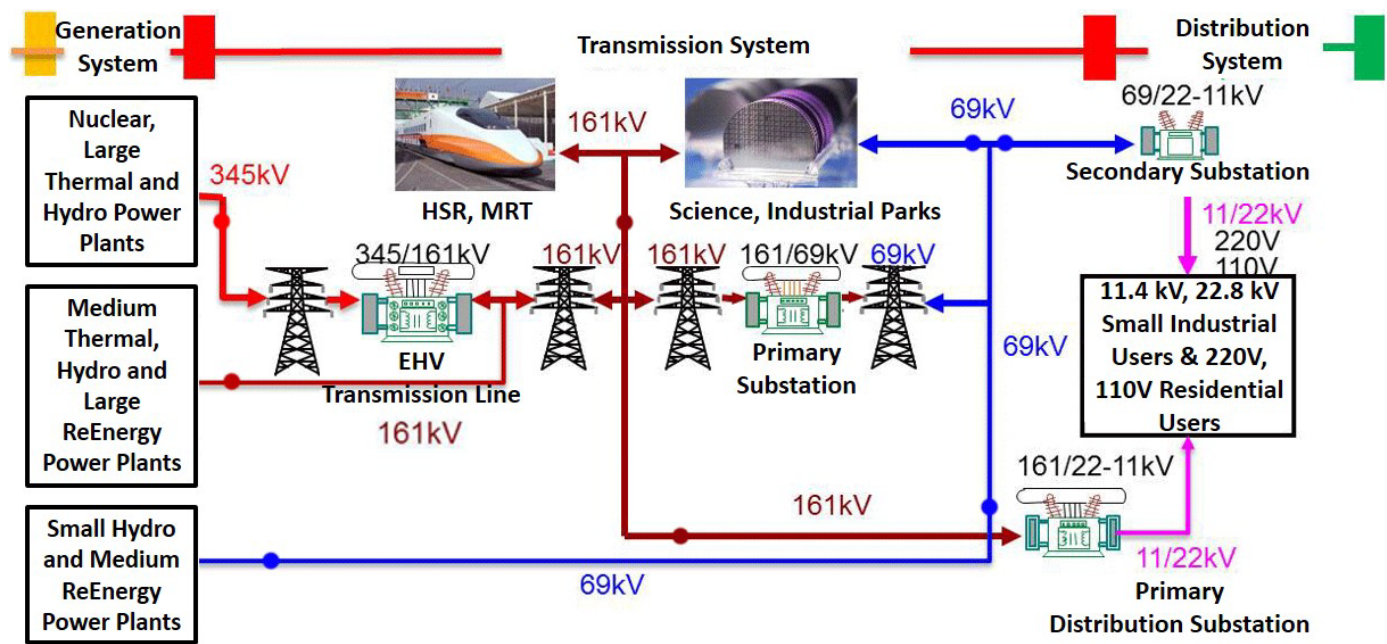

Source: Taipower, available at: http://www.taipower.com.tw/content/new info/new info-c21.aspx?LinkID=12

Figure 3. Introduction of Taiwan electricity supply system.

voltage again for use in normal homes and civilian electricity; 2) Medium scale hydropower, thermal power and large scale renewable energy power plants; 3) Small scale hydropower and medium scale renewable power plants [3].

The power transmission and distribution line can be divided into three types: 1) $345 \mathrm{KV}$ voltage-level extra high voltage (EHV) transmission power line, Taiwan has three such lines, using large quantity of electric charge, long distance transmission and $4004 \mathrm{KM}$ loop; 2) $161 \mathrm{KV}$ level primary transition line; 3) 69 $\mathrm{KV}$ level secondary transition line. The latter two use regional medium to small sized systems as a backbone with large power systems secondary networks, with a total of 13,281 KM loops [2] [4]. Distribution systems are the broadest link in the electricity grid, taking into account the size of the area and distinct nature of the distribution area, the density of load, system voltage and other factors bring out different patterns [5].

Power grids can be divided into Super high Voltage (SHV), High voltage (HV), Low Voltage (LV) power grids [4]. Power transmission systems include 31 SHV substations $(345 / 161 \mathrm{KV}), 45$ primary transmission substations $(161 / 69 \mathrm{KV})$ and a distribution system including 234 distribution substations (161/22, $11 \mathrm{KV})$ and 293 secondary substations [3]. (Figure 3)

Taiwan's first power grid with the first transmission line was completed in 1951, connecting Hualian to the West coast's electricity system; in 1962 the Hualian Taitung secondary transmission line was completed, connecting Taitung to the west coast electricity system; in 1974 the first $345 \mathrm{KV}$ SHV transmission system line between North and South was completed, at the time Taiwan was the first country in Asia to have a $345 \mathrm{KV}$ transmission system [6].

Taipower's organizational structure includes a power generation division, transmission system division and distribution and service division, in charge of generating, transmitting and distribution of power [7].

There are two ways to construct power transmission and distribution lines: the first is overhead lines, constructing transmission towers, cement poles, with 
one tower connected to the next tower covering the whole of Taiwan. The problem with this method is that it makes use of more land, making it easy to give rise to dispute. Another method is ground cables, building pipelines underground, along with cable conducting installation. In 1974 Taiwan began building Taiwan's first HV underground cables [6].

\section{Regulations on Transmission and Distribution Networks from the Perspective of the Newest Revision of Electricity Act}

The liberalization of Taiwan's Electricity Industry planned to begin in 1995 when the Executive Yuan first sent the draft revision of the Electricity Act to the Legislative Yuan for deliberation, then after in 1999, 2002, 2007, 2008, 2015 and 2016 new amendments to the Electricity Act were sent to the Legislative Yuan. Currently, the newest version of the Electricity Act was revised in January of 2017, in particular with Taiwan having a new ruling party, the Bureau of Energy, Ministry of Economic Affairs once again proposed a new version in 2016. Revisions to the Act were accessible on line, and then gradually convened to discuss, consulting related administrative agencies, civil groups, electricity industry and labor groups to understand various opinions.

The latest Revision of the Electricity Act has 9 chapters, and 97 articles and the revisions made regarding regulations on Transmission and distribution networks are as follows: (please refer to Revision of the Electricity Act)

1) In the future the power industry will be divided into three distinct industries: power generation industry, transmission and distribution industry and electricity selling industry (article 2 item 1 ), each with its individual management.

Taiwan's current electricity market structure is based on one state-run integrated power company combining the business of the generation, transmission distribution and selling of electricity. While the electricity generation department is open to independent power producers (IPP), combined heat and power station, renewable energy power generator, yet besides Taipower, the electricity produced by other sources, legally speaking are only permitted to sell wholesale to Taipower, and are not allowed to sell directly to the consumer. That is to say that Taipower currently holds the exclusive right to the operation of the electricity business (old electricity act article 3 ). In the future users will not be limited to purchasing electricity from Taipower alone. Electricity industry organizations, other than renewable energy generator plants, will be limited to Company Limited by Shares.

2) The transmission and distribution sector will still remain a monopoly

"The transmission and distribution sector is defined as" points to the national installation power grid, providing power for public use (article 2 item 4), "the electricity grid is defined as refers to the demarcation point between the main electricity power generating equipment, the transmission and distribution industry and the user, all belonging to the same electricity transmission system 
with its supporting installations and substation installation." (article 2 item 14) Since the transmission and distribution network possesses both public and natural exclusive properties, by defining the transmission and distribution power industry equipment as "public access" or "common carrier", does the Act maintain the only one state-owned enterprise. The transmission and distribution industry's wheeling of renewable energy power generator's electricity, or renewable energy power generator's can customize an in-house route to directly transmit electricity to users.

3) Transmission and distribution power industry to operate power transmission and distribution network

The transmission and distribution power industry will be responsible for the national power transmission and distribution network, including the planning, construction and maintenance, with an obligation to ensure users are connected, while fulfilling their obligation to ensure interconnecting grid systems for other power industries. It is vital to ensure the fairness of the power grid, equal treatment for all and public provision for all power industry users. This version of the legislation has yet to require the establishing of an independent systems operator (ISO) for the transmission and distribution sector.

4) New organizational design

To coordinate with the development of the transmission and distribution industry, the new organization will have follow qualities. First, having referred to the experience of the UK, US and EU, an Electricity Industry regulatory agency would be assigned by the central competent authority in charge of the stateowned power related business. Secondly, a Platform for Power Trading would be set up by the Transmission and Distribution industry.

5) Concurrent limitations

There are two main limitations: 1) The operation of a transmission and distribution company, in principle, can't operate concurrently in terms of the power generating industry and the electricity selling industry; 2) The transmission and distribution industry supplementing other industries besides the power industry, must not influence its own business operations, nor should it limit competition or cause unfair competition, moreover it should be regulated by the Electricity Industry Regulatory Agency.

As for the power generation industry and normal Power Sales industry, since they count as non-public businesses, they can work in a free competitive market and diversify their businesses, unlike the old Electricity Act with its concurrent limitations.

6) Terms of license permits

The terms of license permits for the electricity industry are all the same, 20 years, once the license permit term comes to an end, the business can apply to the Electricity Industry Regulatory Agency for an extension.

7) The establishment of a power development foundation

This revision of the Electricity Act aims to set up a dry fund, in relation to the transmission and distribution industry: the transmission and distribution indus- 
try and power generating industry should invest a lump sum to establish a power development foundation, with the legal purpose of taking into account businesses' social responsibilities and feeding back to the community and residents of areas around power plant installations.

8) 2025 achieve a nuclear-free homeland

Taiwan currently has four nuclear power plants, the building of the $4^{\text {th }}$ has already been brought to a halt, and there will not be an extension to the life of power plants' $1^{\text {st }}$ to $3^{\text {rd }}$. This revision sets 2025 as a goal for the end of operations at all nuclear plants. Within this context, in order to make up for the lack in the power supply which the end of nuclear power in Taiwan will lead to, it is of vital importance to be proactive in developing forms of renewable energy and strengthening the construction of smart grids to enable the country to cope with the changes that will occur in the energy resources.

In Taiwan's promotion of the liberalization of the power industry, there should be an increase in competition for the power generation market; increasing business operations efficiency and bringing about growth in power production industry. At the same time the renewable energy industry would be developed, increasing Taiwan's image as a country that promotes green energy and low carbon society within an international community. Fitting this in with the long term plan for promoting the smart grid we can see that it would be contributions to the economy and society as a whole.

\section{Smart Grid}

The concept of developing Smart Grids was one of the main aims of the Executive Yuan's 2010 National Master Plan on Energy Conservation and Carbon Reduction. Beginning in 2009 with the National Energy Conference held by the Ministry of Economic Affairs, the developing of smart power meters and smart grids was set as a principle item for forthcoming promotion, including electrical terminal of the electricity transmission grid, power distribution all the way along to the user clients smart meter, smart grid and this has been written in as one of the principle axis of the National Energy Program for which the Ministry of Science and Technology is responsible, smart grids are also an important bridge to be established to enable greater interaction between the energy industry and information and communication industry. In 2010 the Executive Yuan passed the "Advanced Metering Infrastructure", AMI and in 2011 the Ministry of Economic Affairs Energy Board established a Working Group for the Smart Grid Principle Central Plan, as well as holding a Smart Grid Development Strategies Forum. In 2012 the Executive Yuan passed a Master Plan of Smart Grid in Taiwan, becoming an important policy in the promotion of smart grids, moreover establishing a cross-sector Interdepartmental Promotion Team of Smart Grid, while Tai Power also established a smart grid working group.

According to the definition used in the Master Plan of Smart Grid in Taiwan: "Through data, information and automatic technology, construct an integrated electricity grid integrating power generating, transmission and distribution, 
enabling automatic, secure close coordination between clients and the supply side, promoting greater efficiency in the electricity system's integrated transportation, providing quality and reliable power grid, while promoting the expansion the use of renewable energy and carbon reduction policy goals". And this smart grid can be divided structurally into 6 different aspects, including: Smart Generation and dispatch, smart transmission, smart distribution, smart consumers, smart grid industry and constriction of a smart grid friendly environment. It was estimated in 2011 that the smart grid's development would be separated into three stages, over a 20 year promotion period, these three stages are as follows: Progressively Extending Stage (2011-2015); Promoting Stage (2016-2020), Expansion Use Stage (2021-2030) [8] [9], as shown in Figure 4. An estimated 139.9 billion NTD will be invested into this project; this will be invested correlating with each different stage as shown in Figure 5.

The definition of a smart meter, according to Brendan Cook et al:: A smart meter is a device which monitors a household's electricity consumption in real-time, and has the ability to display real-time pricing in each household [10]. A smart meter is capable of distinguishing between high voltage AMI and low voltage AMI. Between 2010-2012 the Ministry of Economic Affairs Energy Bureau completed the installation of a smart meter model system (Taipei, Xinzhu, Tainan), by the end of 2015, all 24,000 high voltage users, which accounts for $60 \%$ of power utilization in Taiwan, and 10,000 low voltage users, had already installed smart meters [11].

Taiwan's first Smart Grid Demo Site and AMI is currently installed in Penghu [12], There are other demo sites such as smart user energy management system demo sites in a number of places including Tainan, Academia Sinica, convenience stores, science parks, China oil company, along with smart power distribu-

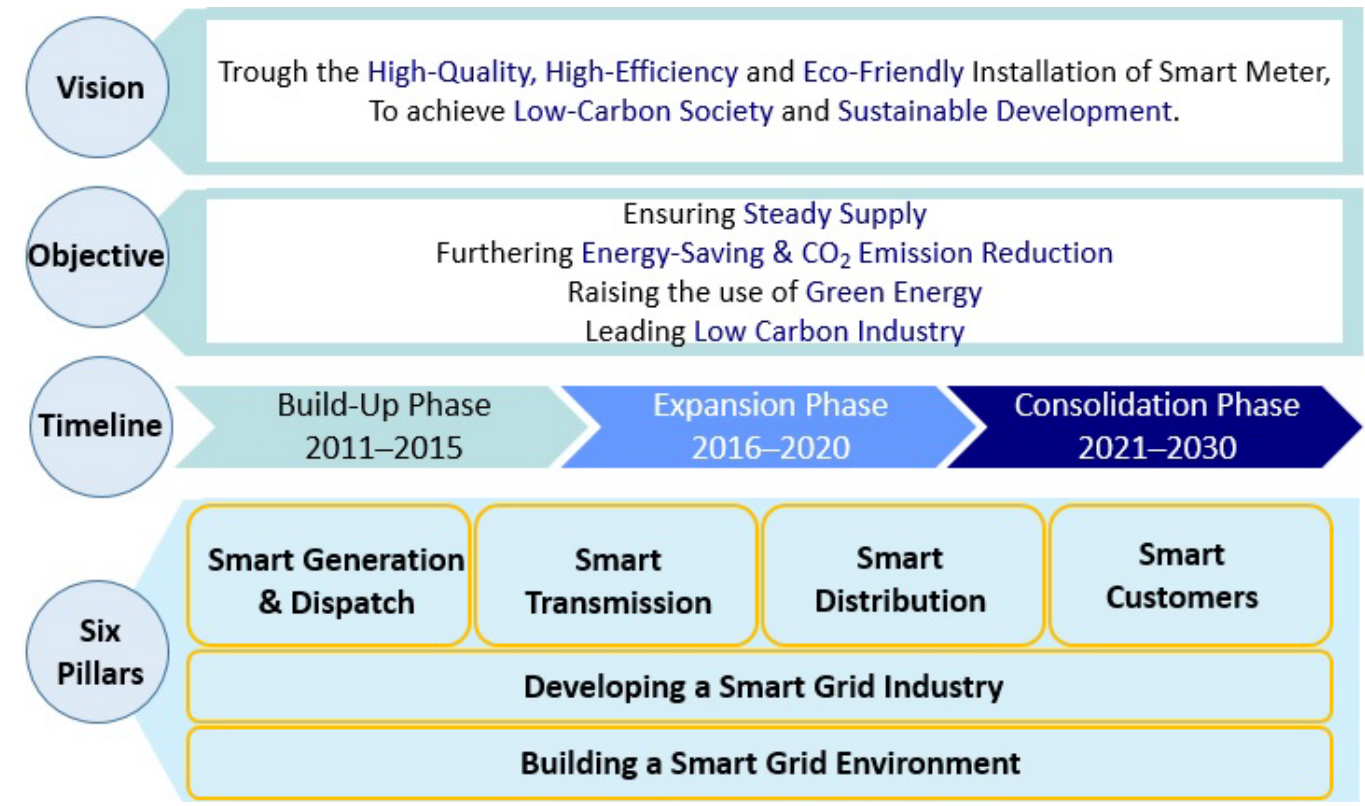

Source: Bureau of Energy, Ministry of Economic Affairs, R.O.C., General Program of Smart Grid

Figure 4. General Framework of Smart Meter. 


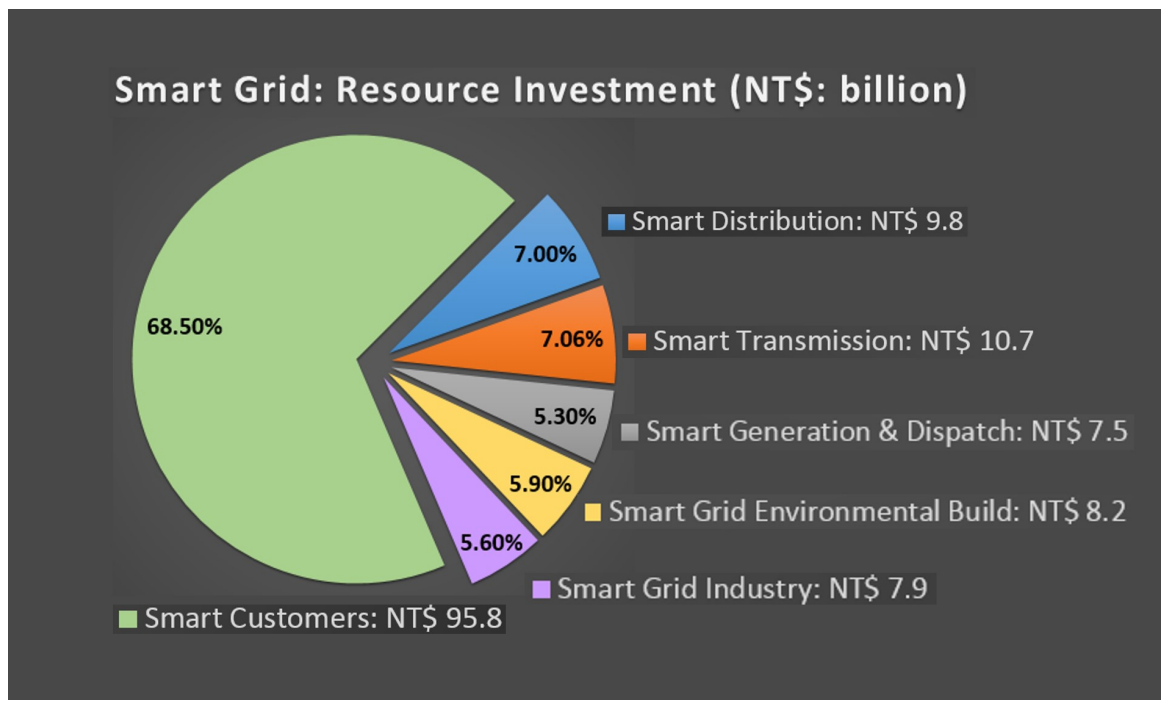

Source: Bureau of Energy, Ministry of Economic Affairs, R.O.C., General Program of Smart Grid.

Figure 5. Smart Grid: Resource Investment.

tion system technology and virtual power plant technology in various areas and institutions including Tai Power, the Business sector and Jinmen, altogether there are 18 smart grid technology demo sites, installed by the Ministry of Economic Affairs, as well as the technology and business sectors [4] [13].

In terms of important plans for developing smart grid use, the National Energy Program-Phase II, included a "smart grid major central plan"1 [14]. In terms of the smart grid industry there are currently two important associations: the Taiwan Smart Grid Industry Association and Taiwan Smart Energy Industry Association. In terms of the market, the market for building grid foundations can be divided into three main kinds: electricity wiring, substations and control facilities and terminal facilities [4].

In terms of regulations regulating the construction of smart grids, including the Electricity Act, Grid Interconnection Code of Renewable Energy, Regulation of Exterior/Interior Circuit Installed [15], and others such as the Energy Management Act, Renewable Energy Development Act are all related in some way [16], besides this there are also related issues such as information security, privacy rights that have related regulations [17] [18], intellectual property rights related regulations, building standardization and authentication systems and so on related standards [19].

Under the larger energy policy goals for the promotion of renewable energy, smart grids play an irreplaceable role, as smart grids enable the promotion of large scale generation of renewable energy into the grid. Smart grids combine smart meter, enabling management of demands, reducing $\mathrm{CO}_{2}$ emissions [4].

\footnotetext{
${ }^{1}$ Taiwan is currently executing a two phased National Energy Program, each stage taking five years, with the first phase running between 2009-2013 and the second going from 2014-2018. The second phase of the National Energy Program focus on 6 main areas: energy conservation, alternative energy, smart grid, offshore wind power and marine energy, geothermal and gas hydrates, carbon reduction and clean coal. See the introduction of National Energy Program-Phase II, National Energy Program Phase II office, 2014.
} 
Through implementing smart grids, electricity systems will be able to ensure high level operations, improving the quality of electricity provision and systems security [20]. As for the development and improvement of smart grids nationally, this is affected by the promotion policies of the government that are dependent on a number of factors including the progression of power electronics, smart grid information and smart meter [21].

As for South Korea's legislation related to promoting smart grids, in 2011 the Smart Grid Promotion Act was passed providing a sustainable smart grid development planning framework. While in the aftermath of Japan's Fukushima nuclear disaster the adoption of smart meters helped to manage demand. Under this context the Ministry of Economy, Trade and Industry (METI) continued to promote the construction of smart grids [22]. While in China smart grids are listed as part of the $12^{\text {th }}$ Five-Year Plan as an important industry in the strategic development of new industries, the planning for which is separated into seven main areas: generated power, transmission of power, substations, allocation of power, power utilization, scheduling and communication platform [8]. In Taiwan smart grids were included in the energy policy as a priority for promoting in 2009 and now have already entered the second stage, though as yet no special law has been formulated.

\section{Integration of Renewable Energy into the Grid}

Due to the market penetration rate and intermittent characteristic of renewable energy, once large amounts of renewable energy is incorporated into the grid, it will have a direct affect on the quality of electricity provision and reliability [23]. Many countries when allowing renewable energy to be connected to the grid have provided standards for the management and technology of such challenges including variation in voltage, frequency etc.; in order to ensure the flexibility of grid transmission once renewable energy is connected to the grid, standards were also put into place : voltage regulations, information data etc.; as well as grid operation, real-time pricing are all aspects which can be regulated through establishing standards to respond to the challenges that the connection of renewable energy to the grid could give rise to [24]. In terms of the extent to which legislation covers these issues, amendments have been made to current legislation to respond to the newest development trends in the electricity grid, as well as making new laws to regulate the future of electricity grid's modernization, and the challenges that smart technology could give rise to. Take for example Germany's Power Grid Expansion Act, EnLAG.

The key legislation for Taiwan's implementation of renewable energy being incorporated into the grid is the Renewable Energy Development Act Item 8: "Renewable energy power facilities and the generation of electricity power shall have the stability of their power grids evaluated by local electric power grid enterprises and have them paralleled and bought wholesale at the locations where existing power grids are closest to renewable energy power assembly sites and provide electricity required by such power facilities during maintenance shut- 
down period; electricity enterprises shall not reject the aforesaid request without proper reason and approval of the central competent authority." In particular this emphasizes the sharing of costs: other than the existing circuits, the cost for power grid enhancement will be shared between both the electricity enterprises and renewable energy power facility installers. The rising cost for the enhancement of the power grid is for example the expansion of current lines, increasing related transformers, or user line being changed to larger scale [25]. Moreover, in terms of line costs: The installer shall install and maintain the circuits connecting renewable energy power facilities and power grids. The renewable energy power generation facility installers shall bear the costs incurred.

Besides the regulations mentioned above, other legislation related to gridconnection also include standards related to electricity: for example: regulations related to electric utility circuit installations) (originally known as interior electricity supply power lines installation regulations, Ministry of Economic Affairs Standards); regulation of interior circuit installations) (Ministry of Economic Affairs Standards), along with business regulations as set out by Taipower: for example Taipower's Guide to Renewable Energy Electricity Generated System Grid Connection Integration Technique, Taipower's Guideline for energy distribution system planning, Third type (installation capacity less than $500 \mathrm{KW}$ ) Renewable energy self-use Electricity generating equipment parallel connection framework [25]. Renewable energy electricity generating system grid-connection technique framework regulating renewable energy grid-connection power distribution system electricity voltage level and capacity limits, stipulating renewable energy equipment grid-connection protection support plan, design and installation standards along with grid-connection transmission demands [26]; Besides this, Taipower established the renewable energy electricity generation gridconnection capacity inquiry system, enabling users to check grid-connection capacity for their area with the intention of applying for grid-connection.

In terms of the constructing of the electricity grid, research points out that legislation's inability to coordinate with developments is the largest barrier against policies attempting to promote the extension of the electricity grid, with an influence far greater than that of the development maturity of electricity grid technology. This Legislation barrier includes: permission procedure delays, the procedure itself being too complicated and lacking transparency; nationally, there are a lack of well planned, long-term guidelines for the expansion of grid; internationally, there is also a lack of planned cooperation. The issues mentioned above show that there is a failure on the part of both the standard system content and implementation process. Sometimes the current standards themselves might be the greatest obstruction to development. In order to eliminate this legislation barrier to development, rather than pointing out small adjustments to be made within the narrow range of current legislation in terms of revisions to specific content or improvements to the legal body at an implementation level, there is a need for significant changes to be made to the regulatory framework itself [27]. 


\section{US and EU Development}

The US legal system and the legal process in relation to smart grids, is closely related to the development some bills related to US electricity market [28]: In 1965, the northeast experienced its first power failure, in 1977 the Federal Power Commission (FRC) reformed as the Federal Energy Regulatory Commission (FERC), then in 1978 the National Energy Act was passed, which then led to the Public Utilities Regulatory Policies Act (PURPA). In 1992 the Energy Policy Act was passed and then in 2003 Northeast once again experienced a power failure, following this in the years 2005, 2007 and 2009 the 2005 Energy Policy Act, Energy Independence and Security Act (EISA07) and the American Recovery and Reinvestment Act (ARRA09) were each passed respectively. Of these Acts the Energy Independence and Security Act directly dealt with Smart Grids and added related regulations, in Title XIII specified the "Statement of policy on modernization of electricity grid", a "Smart grid advisory committee" and "Smart grid task force", "Smart grid technology research, development, and demonstration" and so on. Then the American Recovery and Reinvestment Act set a budget to invest in the development of Smart Grid, including Smart Grid Investment Grant Program, Smart Grid Demonstration Program [29]. In terms of policy, in 2003 the U.S. Department of Energy proposed the "'Grid 2030': A National Vision for Electricity's Second 100 Years", in 2012 it proposed the "2010 Smart Grid Report" [30].

As for EU, their smart grid legislation is related to climate change and energy policy: the EU's 20-20-20 strategic goals and the Strategic Energy Technology Plan (Set-Plan) and other related initiatives such as the European Electricity Grid Initiative (EEGI) the plan of which is part of the Set-Plan. In 2005 the EU established the Smart Grids European Technology Platform; in 2009 the Third Energy Package goal was to complete the Internal Energy Market. The EU's R\&D Framework Programme (FP6, FP7) all support smart grid development, according to the newest R\&D Framework Programme (Horizon 2020), between 2014-2020 the EU will invest an estimated 80 billion euros into research innovation plans, on a theme called "Societal Challenge" directly related to smart grid and referred to as Secure, clean and efficient energy [31]. The EU's Electricity Directive Appendix I.2 demands that member states develop a smart grid system plan in compliance with the directive and establish a time frame for its development by the $3^{\text {rd }}$ September 2012 [32]. Other related legislation include the Energy Infrastructure Package, the Regulation on Energy Market Integrity and Transparency and the Energy Efficiency Directive. In 2011 the EU Committee proposed the Connecting Europe Facility (CEF) legislation package, with goals for improving energy, transport, information these three connected infrastructures [33]. The future development of the EU's electricity grid will be closely related to whether or not they achieve the 20-20-20 goals.

\section{Conclusions}

As a result of the rapid development of renewable energy, advancements in digital technology and the growing connection between energy and information 
technology, the electricity grid is currently in a period of reform. And while this could benefit aims to ensure energy saving and improvement of energy efficiency, reliability and security are still the electricity market's major principles within the electricity provision process.

Taiwan's electricity supply system is actually made up of three systems: the north, central and south systems, of these systems the northern system's supply and demand are the highest. The Transmission system includes high voltage substations and primary substations; power distribution systems include power distribution substation and secondary substations; altogether Taiwan has three high voltage transmission electrical lines. Currently the electricity market is dominated by the state-owned Taipower; however the liberalization of the power industry is currently under way and is already in full spring. In January of 2017 the Revision of Electricity Act is passed. Transmission and distribution grid have been defined as a common carrier, maintaining state-owned monopoly, not opening up to competition. The Amendment plans for Taiwan to become a nuclear free country by 2025.

As for the Smart meter, in 2010 the Executive Yuan passed the Advanced Metering Infrastructure, (AMI) plan; currently high voltage users' installations have already fulfilled the quota set in the AMI plan, while low voltage users installations are on track for reaching targets. As for the Smart grid, policy is mainly based on the "Smart Grid Principle Central Plan" passed by the Executive Yuan in 2012, and is separated into six facets, including Smart Generation and dispatch, Smart Transmission, Smart distribution, Smart Consumers, Smart Grid Industry and Smart Grid Environment Construction. Beginning in 2011 the promotion of Smart Grid has been separated into three stages; and currently development has reached the stage of having built demo sites, accumulating experience and persisting in pushing forward, in terms of national plans; the development of smart grid is being pushed through the Smart Grid Major Central Plan. Renewable energy grid-connection is mainly based on Renewable Energy Development Act article 8, related to strengthening electricity grid pricing, as the current legislation states that renewable energy generators and electricity generating enterprises should share the burden. Other legislation influencing the grid-connection issue, is the Ministry for Economic Affairs, the electricity related executive directive and Taipower company's business regulations, Taipower has also set up a renewable energy electricity generator grid-connection capacity inquiry system, which enables one to directly confirm the actual gridconnection capacity. In order to respond to the intermittent characteristic of renewable energy, when connecting to the grid, it will have a direct affect on the stability and reliability of the grid; therefore there is a need to learn from the US, $\mathrm{EU}$ and other countries experience and methods in developing grid-connection techniques, management methods and general standards.

\section{References}

[1] Chang, C.A., Lan, B.R., Lin, Y.J., et al. (2014) Challenges in the Development of Smart Grid and Renewable Energy. Journal of Taiwan Energy, 1, 259-281. 
[2] Zeng, J.-R. (2015) The Transmission of Electricity from the South to the North. Energy Monthly.

[3] Taipower Website (2016)

http://www.taipower.com.tw/content/new info/new info-c21.aspx?LinkID=12

[4] Taiwan Smart Grid Industry Association Website (2016) Understanding the Smart Grid. http://www.smart-grid.org.tw/

[5] Wang, Y.C. and Huang, Q.T. (2014) The Development and Challenge of Smart Distribution Grid. Journal of Electrical, 168, 76.

[6] Zhu, R.Y. (2010) The Transmission Line System of Taiwan Power Company Which Covers the Whole of Taiwan. Yuan Magazine, 79, 5-6.

[7] Taiwan Power Company (2015) Taiwan Power Company Sustainability Report. Report, Taiwan Power Company, Taiwan.

[8] Bureau of Energy, Ministry of Economic Affairs (2012) The Smart Grid Master Plan.

http://web3.moeaboe.gov.tw/ecw/populace/content/SubMenu.aspx?menu id=1946

[9] Bureau of Energy, Ministry of Economic Affairs (2012) Program of Smart Grid Promotion Workforce.

http://web3.moeaboe.gov.tw/ecw/populace/content/SubMenu.aspx?menu id=1946

[10] Cook, B., et al. (2012) The Smart Meter and a Smart Consumer: Quantifying the Benefits of Smart Meter Implementation in the United States. Chemistry Central Journal, 6, S5. https://doi.org/10.1186/1752-153X-6-S1-S5

[11] Bureau of Energy, Ministry of Economic Affairs (2015) Energy Statistics Year Book. http://web3.moeaboe.gov.tw/ecw/populace/content/SubMenu.aspx?menu id=1946

[12] Chen, X.X. (2015) Plan for Smart Grid Technology Applications. Energy Monthly, $11,34$.

[13] Chen, Y.H. (2014) The Current Status and Prospects of Taiwan's Smart Grid Industry. Taiwan Economic Research Monthly, 37, 17-18.

[14] National Energy Program Phase II office (2014) The Introduction of National Energy Program-Phase II. http://www.nepii.tw/language/en/about-nep-ii/introduction/

[15] Bureau of Energy, Ministry of Economic Affairs (2012) Briefing on the Smart Grid Master Plan.

http://web3.moeaboe.gov.tw/ecw/populace/content/SubMenu.aspx?menu id=1946

[16] Lee, K.Y. (2009) A Discussion and Response to Research Analysis on the Issue of Key Legislation Related to the Smart Grid. Science \& Technology Law Review, 12.

[17] Su, W.X. and Lee, K.Y. (2012) Industry R\&D Invests in Intelligent Energy for Privacy Protection and Information Security in Response to Suggestions-A Case Study of European Union Promoting Legal Policy. Science \& Technology Law Review, 49.

[18] Zeng, Y.X. (2016) A Brief Discussion of the Importance of My Country's Key Energy Related Infrastructure Information and Communication Technology (ICT) Security Legal Structure-An Example from the Progressive Development of the EU and Germany's Smart Meter. Science \& Technology Law Review, 18.

[19] Chen, Z.X. (2015) Countermeasure Research on the Trend of Smart Grid Technology Development and Renewable Energy Integration into the Grid. Journal of Taiwan Energy, 2, 148.

[20] Brown, M.A. (2014) Enhancing Efficiency and Renewable with smart Grid Technologies and Policies. Futures, 58, 30. https://doi.org/10.1016/j.futures.2014.01.001 
[21] Hossain, M.S., et al. (2016) Role of Smart Grid in Renewable Energy: An Overview. Renewable and Sustainable Energy Reviews, 60, 1182. https://doi.org/10.1016/j.rser.2015.09.098

[22] Tuballa, M.L. and Abundo, M.L. (2016) A Review of the Development of Smart Grid Technologies. Renewable and Sustainable Energy Reviews, 59, 710-725. https://doi.org/10.1016/j.rser.2016.01.011

[23] Taiwan Power Company (2013) The Impact and Influence of Japan's Fukushima Nuclear Disaster on the Energy Policy and Direction of Reform in Taiwan's Power Industry as Well as the World's Major Countries. Report, Taiwan Power Company, Taiwan.

[24] Chen, Z.X. (2015) Countermeasure Research on the Trend of Smart Grid Technology Development and High Renewable Energy Grid Operation. Journal of Taiwan Energy, 2, 146-147.

[25] Chen, Y.C. (2015) Renewable Energy Integration into the Grid Operation Practices. Taiwan Power Company Tainan District Office, Taiwan.

[26] Wang, Y.C. and Huang, Q.T. (2014) The Development and Challenge of Smart Distribution Grid. Journal of Electrical, 168, 77.

[27] Battaglini, A., et al. (2012) Perception of Barriers for Expansion of Electricity Grids in the European Union. Energy Policy, 47, 254-259. https://doi.org/10.1016/j.enpol.2012.04.065

[28] Simões, M.G., et al. (2012) A Comparison of Smart Grid Technologies and Progresses in Europe and the U.S. IEEE Transactions on Industry Applications, 48, 1154-1162. https://doi.org/10.1109/TIA.2012.2199730

[29] Huang, Y.S. (2013) Smart Grid Promotion Policy in the United States (Part 1). Electricity Monthly, 23, 167.

[30] Huang, Y.S. (2013) Smart Grid Promotion Policy in the United States (Part 1). Electricity Monthly, 23, 164-165.

[31] Crispim, J., et al. (2014) Smart Grids in the EU with Smart Regulation: Experiences from the UK, Italy and Portugal. Utilities Policy, 31, 88.

https://doi.org/10.1016/j.jup.2014.09.006

[32] Chen, Y.H., et al. (2012) An Introduction to the Promotion of Smart Grid in Key Countries. Electricity Monthly, 22, 8.

[33] Crispim, J., et al. (2014) Smart Grids in the EU with Smart Regulation: Experiences from the UK, Italy and Portugal. Utilities Policy, 31, 87-89.

https://doi.org/10.1016/j.jup.2014.09.006 
Submit or recommend next manuscript to SCIRP and we will provide best service for you:

Accepting pre-submission inquiries through Email, Facebook, LinkedIn, Twitter, etc. A wide selection of journals (inclusive of 9 subjects, more than 200 journals)

Providing 24-hour high-quality service

User-friendly online submission system

Fair and swift peer-review system

Efficient typesetting and proofreading procedure

Display of the result of downloads and visits, as well as the number of cited articles Maximum dissemination of your research work

Submit your manuscript at: http://papersubmission.scirp.org/

Or contact sgre@scirp.org 